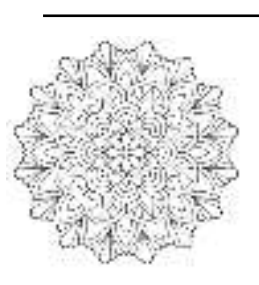

AL HIKMAH: INDONESIAN JOURNAL OF EARLY CHILDHOOD ISLAMIC EDUCATION

ISSN (P): 2550-2200, ISSN (E): 2550-1100,

VOL. 5 (1), 2021, PP. 27 - 38

http://journal.iaialhikmahtuban.ac.id/index.php/ijecie

\title{
TUMBUH KEMBANG ANAK DAN POLA PENGASUHAN ORANG TUA PADA MASA GOLDEN AGE DI RA VINNAJA KABUPATEN MUARO JAMBI PROVINSI JAMBI
}

\author{
Nurul Annisa De wantari Nasution ${ }^{1}$, Vivi Yumarni ${ }^{2}$, Siti Marwah ${ }^{3}$ \\ ${ }^{1,2,3}$ Program Studi Pendidikan Islam Anak Usia Dini, STAI Ma'arif Jambi \\ nurian.8605.nst@gmail.com
}

\begin{abstract}
Tujuan dari penelitian ini adalah untuk mengetahui apakah pola asuh yang diterapkan oleh kedua orang tua sudah mengikuti metode yang telah ditentukan yaitu berupa pendekatan, pembiasaan dan pelayanan (metode katsayan). Orang tua dan keluarga merupakan wadah pendidikan yang sangat besar pengaruhnya dalam perkembangan anak, oleh karena itu pendidikan anak tidak dapat dipisahkan dari keluarganya. Karena keluarga merupakan tempat pertama kali anak menyatakan diri sebagai makhluk sosial dalam berinteraksi dengan lingkungannya dan kelompoknya. Kegiatan ini adalah sebagai salah satu wujud pengabdian kepada masyarakat, program studi Pendidikan Islam Anak Usia Dini (PIAUD) STAI Ma'arif Jambi. Pelaksanaan penelitian ini berupa kegiatan PKM yang merupakan penelitian deskripstif kualitatif. Dan kegiatan ini sebagai sabjek nya adalah anak Raudathul Athfal VINNAJA desa kasang kota karang rt, 03, kecamatan kumpeh ulu, kabupaten muaro jambi, para guru dan orang tua yang ada di sekitar sekolah. Hasil dari penelitian ini di ambil dari kegiatan lomba menggambar menggunakan alat cutton bath (sebagai kuas) untuk menggambar dan di dampingi oleh orang tua. Dan seminar untuk orang tua (wali murid) sebagai pengayaan ilmu terhadap orang tua yang ada di RA vinnaja tersebut, adapun parenting islam ini di adakan dengan tema "Tumbuh kembang anak dan pola pengasuhan orang tua pada masa golden age" dengan tim pelaksana yaitu Vivi Yumarni. M.Pd.I, sedang kan pematerinya Siti marwah. S Ag. MPd.I, dan nurul annisa DN. S.Psi M. Pd. Maka dengan di laksanakan kegiatan ini kami mengharapkan orang tua dapat menerapkan metode katsayan (pendekatan, pembiasaan, pelayanan) pada anak- anak nya.
\end{abstract}

Abstrak

Kata kunci: parenting islam, tumbuh kembang anak dan pola pengasuhan pada masa golden age.

\section{Abstract}

The purpose of this study was to determine whether the parenting styles applied by both parents had followed the predetermined methods, namely in the form of approach, habituation and service (the katsayan method). Parents and families are educational institutions that have a very big influence on children's development, therefore children's education cannot be separated from their families. Because the family is the first place where children claim to be social beings in interacting with their environment and groups. This activity is a form of community service, the STAI Ma'arifJambi Early Childhood Islamic Education study program. The implementation of this research is in the form of PKM activities which are descriptive qualitative research. And this activity as a sabjek is the child of Raudathul Athfal VINNAJA, Kasang village, Karang City Rt, 03, Kumpeh Ulu sub-district, Muaro Jambi district, teachers and parents around the school.The results of this study were taken from a drawing competition using a cutton bath (as a brush) to draw and accompanied by parents. And seminars for parents (guardians of students) as an enrichment of knowledge for parents in RA vinnaja, while Islamic parenting was held with the theme "Child development and parenting patterns during the golden age" with the implementing team, namely Vivi Yumarni. . M. Pd.I, while the speaker was Siti Marwah. S Ag. M Pd.I, and Nurul Annisa Dewantari Nasution, S.Psi M. Pd. So by carrying out this activity we hope parents can apply the katsayan method (approach, habituation, service) to their children.

Keywords: Islamic parenting, child development and parenting patterns during the golden age. 
PENDAHULUAN

Dalam kehidupan keseharian anak-anak mempunyai perilaku yang berbeda-beda, ada anak yang mandiri, mudah beradaptasi , mudah bersosialisasi, tidak mudah menangis, disiplin rajin dan cerdas, anak yang sangat tergantung pada orang tuanya atau gurunya, pendiam, pemurung, mudah menangis, dan kurang responsif. Beragam perilaku tersebut menimbulkan pertanyaan yang perlu ditindaklanjuti yakni, mengapa hal ini dapat terjadi? Bahkan dalam satu keluarga sekalipun dimana anak pertama berbeda perilakunya dengan anak kedua. Meskipun setiap anak dilahirkan dalam keadaan suci belum ternodai, Lingkungan berperan besar dalam menorehkan tinta dalam kehidupan mereka.

Pertumbuhan dan perkembangan anak merupakan hal yang seharusnya diperhatikan dan dijaga dengan baik, karena 2 hal tersebut adalah indikator penting berpengaruh terhadap kualitas hidup sang anak di masa depan. Sudah seharusnya orang tua memprioritaskan tumbuh kembang anak. Sesungguhnya sejak awal prenatal (dalam kandungan), orang tua telah siapkan mental dan fisik untuk menjaga tiap pertumbuhan dan perkembangan anak tersesbut. Hal ini bisa dilakukan dengan kerjasama antara sang Ayah dan Ibu dalam menjaga kandungan, seperti memperhatikan asupan gizi sang ibu yang nantinya juga akan berpengaruh pada tumbuh kembang baik seperti yang diharapkan oleh orang tuanya tersebut.

Setelah anak dilahirkan (post-natal), maka dari awal masa pertumbuhan emas (golden age) yaitu pada usia 0-6 tahun, orang tua bisa lanjutkan pemberian perhatian khusus pada proses tumbuh kembang anak. Hal ini dikarenakan, masa ini adalah masa dimana anak-anak berkembang dengan sangat cepatnya, misalnya saja dalam hal penyerapan informasi yang dia terima di lingkungan sekitarnya anak-anak tergolong memiliki penyerapan informasi yang cepat, sehingga bisa dikatakan anak-anak usia emas ini adalah sang peniru ulung. Jadi, orang tua atau pihak keluarga lainnya harus lebih berhati-hati dalam pengucapan kata-kata maupun berperilaku di depan anak-anak. Untuk menjadi orang tua pun kita tak henti-hentinya harus banyak belajar yaitu dalam hal pola pengasuhan yang tepat guna yang bisa kita terapkan pada anak-anak usia dini ini.

Menurut pakar ilmu Islamic Parenting yaitu Ustadz Yusuf Utsman Baisa, Lc menyatakan bahwa pengasuhan itu bukanlah suatu pengajaran. Dimana pengajaran adalah transfer of knowledge, proses pemindahan ilmu pengetahuan dari otak guru ataupun buku kepada otak murid. Sedangkan pengasuhan adalah proses mentransformasi, mengubah, memindahkan ilmu yang telah didapatkan oleh anak di sekolah atau lembaga pendidikantadi berupa teori berubah menjadi praktek, kemudian konsep yang didapatkan anak berubah 
menjadi aplikasi/implementasi. Dalam proses tersebut, maka dibutuhkannya suatu metode untuk mencapai keberhasilan dalam mengasuh. Metodenya yaitu berupa pendekatan, pembiasaan dan pelayanan atau disingkat dengan nama metode katsayan.

Berangkat dari kewajiban mengasuh, setiap orang baik laki-laki maupun perempuan punya kewajiban untuk mengasuh. Dimulai dari mengasuh dirinya sendiri, mengasuh orang lain, mengasuh anak, mengasuh istri atau sebaliknya. Mengasuh itu bagian dari kewajiban dimana terdapat dalam potongan ayat QS. Al-Ashr ayat 3 yaitu: “...wa tawaa shoubil haqqi wa tawaa shoubis sabr" yang artinya: “...saling menasehati untuk kebenaran dan saling menasihati untuk kesabaran." Kita tahu bahwa sabar itu adalah kuncinya hidup. Siapapun ingin sukses, maka dia harus sabar. Orang yang tidak sabar dia akan gagal.

Metode katsayan terdiri dari 3 patahan kata, yaitu dari kata kata pendekatan, pembiasaan dan pelayanan. Metode pengasuhan berupa pendekatan terdiri dari 4 proses yaitu: tahap mengenali adalah dengan mengenali identitas, bakat, minat dan hobi anak. Selanjutnya tahap memahami yaitu memahami perubahan-perubahan emosi pada diri anak, kemudian tahap memberikan perhatian dengan bersikap tanggap dalam pmberian perhatian dari orang tua, yang terakhir tahap berbagi yaitu berbagi kepada anak berupa pengalaman-pengalaman.

Metode pengasuhan yang kedua adalah metode pembiasaan, dimana setelah anak kembali ke rumah dari sekolah maka yang bisa dilakukan orang tua adalah mengubah ilmu yang didapatkan dari sekolah menjadi amalan, teori diubah menjadi praktek, dan sebuah konsep diubah menjadi aplikasi.Sebagai salah satu contoh pembiasaan ibadah shalat yang kita terapkan kepada anak-anak kita, sebagaimana hal tersebut terdapat dalam QS. Thaha ayat 32 yang artinya: "Dan perintahkan keluargamu untuk melaksanakan shalat dan bersabarlah dalam mengerjakannya.'Berdasarkan HR. Ahmad Abu Daud At-Turmudzi: "Perintahkan anak-anakmu untuk shalat saat usia 7 tahun, dan pukul mereka apabila mereka tidak shalat pada usia 10 tahun". Pukul disini adalah bukan pukulan yang menimbulkan sakit dan bekas, namun pukul dengan kasih sayang, tidak menceridai dan dengan didikan yang dapat membuat anak menuruti perintah untuk melaksanakan shalat.

Dijelaskan juga menurut Al-Addabu Sa'liyah, menyatakan bahwa sesungguhnya melatih jiwa harus diajari, dibisakan untuk beradab, juga pembiasaan berbuat baik. Jika perbuatan itu baik yang terus dilakukan terus menerus secara berulang maka akan menjadi kebiasaan, kemudian jadi tabiat/karakter/watak dan adab-adab kebiasaan. Metode yang ketiga adalah pelayanan, kita mengacu kepada salah satu ayat dalam QS. At-Taubah ayat 128 yang artinya: "Telah datang dari kalian seorang rasul dari diri kalian sendiri, dia akan merasa 
sedih/kesulitan, dia sangat peduli kepada kalian dan sangat pengasih dan penyayang terhadap orang-orang beriman. ”HR. Muslim: “Allah akan terus menyertai seorang hamba, selama hamba itu terus melayani atau menolong orang lain."Mujahid seorang tabi'in rahimahullah menceritakan tentang gurunya yaitu Abdullah Ibn Umar beliau berkata. Aku menemani Ibn Umar untuk melayaninya, namun yang terjadi dia yang melayani aku. Bahkan dialah yang menaikkan aku keatas kuda ku dan dia pulang merapikan baju-bajuku.Jadi, inilah yang dimaksud dengan metode katsayan, yang sesungguhnya terambil dari ayat-ayat AlQur'an dan hadits-hadits yang shahih juga dari ungkapan para ulama dan para sahabat radiyallahu'anhumma ajma'in.

Menurut ustadz Yusuf Utsman Ba'isa, Lc dan Ustadz Dr.SyafiqRizaBasalamah metode katsayan sejatinya kembali kepada orang tua, sadar tidak orang tua itu tanggung jawab terhadap anak-anaknya, tanggung jawab mendidik anak sepenuhnya bukan tanggung jawab pihak sekolah. Allah Subhanahuwata'ala berfirman: Buat apa ketika orang tua ingin punya anak? Semua yang dilahirkan itu di atas fitrah atau suci.Maka untuk selanjutnya orang tua lah yang membentuk anak tersebut.

Tujuan dari penelitian ini adalah untuk mengetahui apakah pola asuh otoriter, demokratis dan permisif secara bersama-sama menunjukkan adanya hubungan dengan perkembangan nilai moral agama, sosial emosional, bahasa, kognitif dan fisik motorik. Penelitian ini dilakukan sampel sebanyak 15 siswa yang ada pada RA VINNAJA desa kasang kota karang kecamatan kumpeh ulu kabupaten muaro jambi yang diajukan dalam penelitian hanya hipotesis utama tidak merinci lebih jauh pada bagian-bagian yang lebih kecil. Adapun hipotesis yang diajukan adalah terdapat hubungan secara bersama-sama antara pola asuh demokratis, otoriter, permisif dengan perkembangan nilai moral dan agama, perkembangan sosial emosional, perkembangan bahasa, perkembangan kognitif, perkembangan fisik. Analisis data penelitian menggunakan teknik korelasi kanonikal. Pengolahan data korelasi kanonikal dalam penelitian ini menggunakan bantuan program perkembangan moral agama, soasial emosional, bahasa, kognitif, dan fisik motorik.

\section{METODE}

Metode pelaksanaan program pengabdian kepada masyarakat dilaksanakan dalam beberapa tahapan yaitu: tahap perencanaan, tahapan pelaksanaan dan tahapan evaluasi. Adapun tahapan perencanaan ditetapkan dengan penentuan lokasi pengabdian masyarakat tersebut yaitu bertempat di RA Vinnaja Muaro Jambi. Jenis kegiatan adalah workshop 
parenting dengan tema "Tumbuh Kembang Anak dan Pola Pengasuhan Orang Tua pada Masa Golden Age". Tahapan pelaksanaan berupa kegiatan diskusi dan workshop dengan bentuk lomba kreatifitas anak-anak yaitu lomba mewarnai dan penyampaian materi oleh tim kepada para guru dan orang tua.

Kegiatan pengabdian kepada masyarakat menggunakan metode dalam bentuk seminar dan workshop dalam bentuk penyampaian materi dan lomba mewarnai yang dilaksanakan di RA Vinnaja Desa Kasang Kota Karang Kecamatan Kumpeh Ulu, Kabupaten Muaro Jambi Provinsi Jambi. Adapun tahpan-tahampan dalam pelaksanaan kegiatannya berupa seminar, diskusi dan lomba mewarnai. Kelayakan sasaran strategi untuk permasalahan ini yaitu guru PAUD, orang tua dari siswa-siswi PAUD dan siswa PAUD itu sendiri. Alasan dipilihnya sasaran kegiatan ini yaitu karena pesertanya memiliki kemampuan untuk membangun program edukatif parenting secara realistis dan memiliki kemampuan untuk dapat dijadikan sebagai perwakilan dalam perbaikan dan perubahan dalam penerapan metode yang ditawarkan dan dikenalkan oleh pemateri yaitu metode katsayan (pendekatan, pembiasaan dan pelayanan) terhadap pendidikan dan pengasuhan dari orang tua dan guru pada anak-anak usia dini (masa golden age) di RA Vinnaja khususnya. Adapun kualitas penerimaan dari kegiatan pengabdian kepada masyarakat ini adalah dari observasi (pengamatan langsung), serta role playing peserta dalam tahap persiapan, pelaksanaan dan penilaian terhadap pendampingan yang dilaksanakan sehingga mampu memberikan prediksi perihal capaian yang telah didapat oleh peserta terhadap pendidikan anak usia dini yang dijalankan.

\section{HASIL DAN PEMBAHASAN}

Kegiatan ini adalah kegiatan pengabdian kepada masyarakat, yang dilakukan oleh tim dosen dari Program Studi PIAUD STAI Ma'arif Jambi pada awal Maret 2021. Hasil dan pembahasan penelitian dimulai dari observasi, wawancara dan dokumentasi. Data yang telah diperoleh dari hasil tersebut maka kemudian dianalisis oleh peneliti. Dalam hal ini, peneliti menganalisis hal yang berkaitan dengan kegiatan parenting tumbuh kembang anak dan pola pengasuhan orang tua. Kegiatan parenting ini memiliki tujuan agar terciptanya pengetahuan yang lebih, baik untuk orang tua dan juga para pendidik karena dalam kegiatan ini orang tua dan guru dibekali materi dan ilmu tentang salah satu metode yang bisa diaplikasikan oleh mereka dalam menerapkan pola pengasuhan yang baik untuk anak pada masa golden age atau lebih dikenal dengan istilah anak usia dini. Adapun metode pengasuhan tersebut adalah 
metode katsayan (pendekatan, pembiasaan dan pelayanan), metode ini terlebih dahulu diperkenalkan oleh pakar ilmu parenting Islamic yaitu Ustadz Yusuf Utsman Ba'isa, Lc. Berikut akan dijelaskan lebih rinci ketiga metode katsayan:

\section{A. Motode Pendekatan}

Metode Pendekatan ada 4 yaitu:

- Mengenali : kenali identitas, bakat, minat dan hobi anak. Orang tua tentunya mengenali akan pribadi anak-anaknya, mereka tahu akan bakat dan minat serta hobi anak.

- Memahami pahami perubahan emosi anak. Orang tua dengan metode pendekatan ini untuk bisa memahami berbagai bentuk perubahan - perubahan emosi pada anak. Sebagai contoh yang tadinya si anak gembira, namun suatu saat dia lebih murung dan banyak dia, nah disana orang tua bisa dekati si anak kemudian ajak anak untuk mau terbuka bercerita masalah yang sedang dia hadapi.

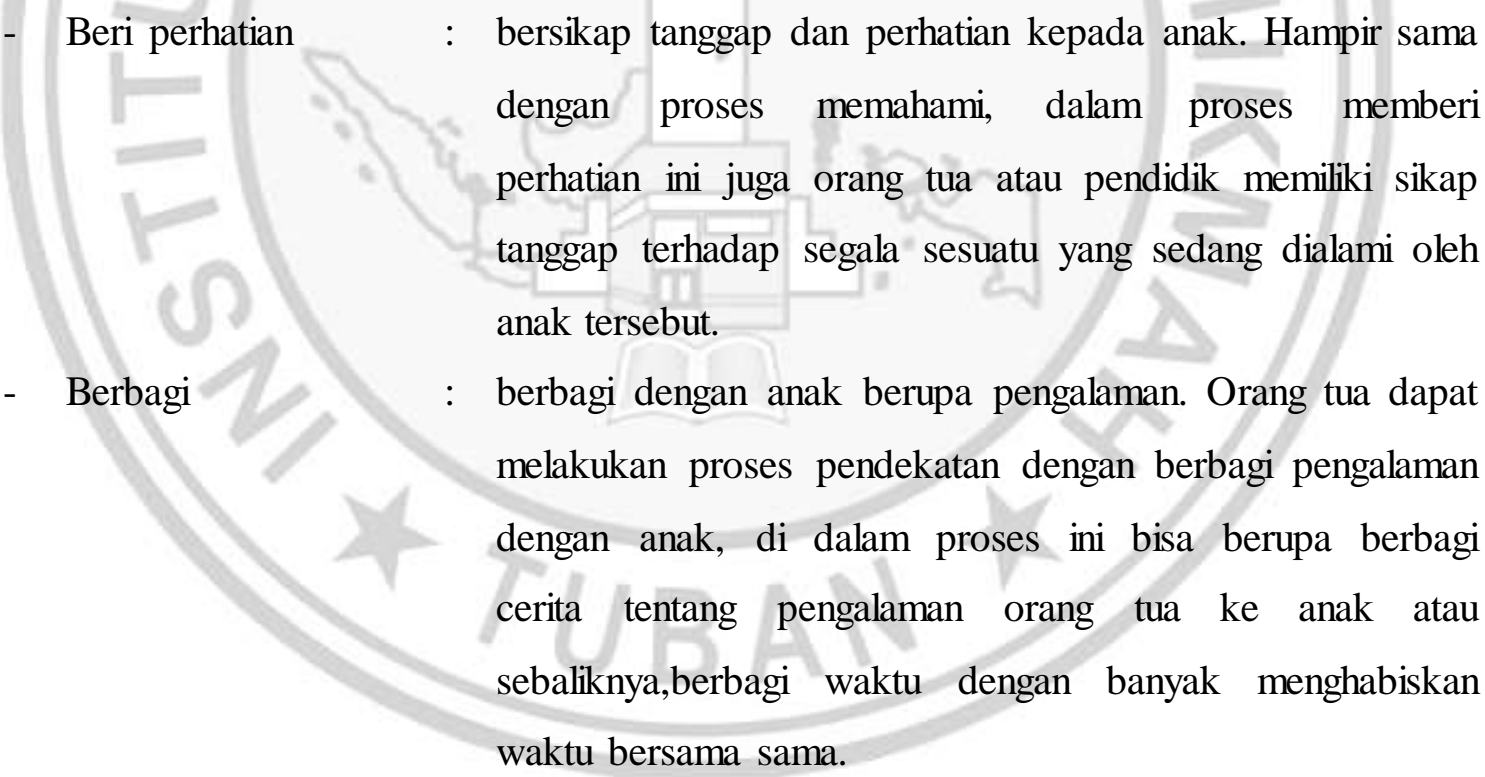

Menurut paparan kajiannya Ustadz Yusuf Utsman Ba'isa, Lc tentang “diskusi Parenting Islamic dengan metode KATSAYAN" adapun indikator anak dekat dengan orang tua adalah percaya pada orang tua. Terdapat pada ayat $Q S$. Ar-Ra'd ayat 17: "Adapun buih akan pergi tidak bermakna; tetapi yang bermanfaat bagi manusia, akan tetap ada di bumi." Demikianlah Allah Subhanahu wata'ala membuat perumpamaan. Dari keempat proses ini arah atau tujuan yang ingin dicapai dari pendekatan itu agar anak mau menerima program kepengasuhan dari orang tuanya. 
Sejauh metode pendekatan ini orang tua harus mengukur indicator keberhasilan orang tua dalam mendekati. Pendekatan disini tidak hanya kedekatan fisik saja misalnya memberi perhatian kepada anak dengan berpelukan saja, namun kedekatan disini adalah lahirnya kepercayaan pada diri anak sehingga anak itu mau menerima kepengasuhan dari orang tuanya. Orang tua mengasuhnya, dan anak tidak merasa asing dengan kepengasuhan yang dilakukan oleh orang tuanya. Jadi, anak menganggap semua yang dilakukan oleh orang tuanya berupa nasehat, bimbingan dan asuhan itu semua baik untuk diri anak tersebut.

\section{B. Metode Pembiasaan}

Memproses sebuah perubahan itu dengan melakukan pembiasaan, sifat itu adalah hasil dari kebiasaan. Karaktek dan sikap adalah hasil dari kebiasaan yang tertanam oleh orang tersebut selama sekian waktu. Orientasi kepengasuhan dari pembiasaan ini adalah bagaimana proses pembinaan dan pembiasaan ini terus berlangsung, maka itulah keberhasilan dari sebuah pembiasaan.

Dalam metode pembiasaan ini yang bisa dilakukan oleh orang tua yaitu:

- Ilmu akan berubah menjadi amalan dengan pembiasaan-pembiasaan, teori diubah menjadi praktek, dan sebuah konsep dapat diubah menjadi aplikasi.

- Pembiasaan dalam ibadah shalat yang kita terapkan kepada anak-anak kita sebagaimana hal ini terdapat dalam QS. Thaha ayat 132: "Dan perintahkanlah keluargamu melaksanakan shalat dan sabar dalam mengerjakannya..."

- Dalam HR. Ahmad Abu Daud At-Turmudzi: "Perintahkan anak-anakmu untuk shalat saat berusia 7 tahun dan pukul mereka apabila mereka tidak shalat pada usia 10 tahun". Pukul disini adalah bukan pukulan yang menyakitkan dan memberikan bekas, melainkan pukul yang tidak menciredai/dengan didikan dan kasih sayang.

- Kemudian menurut Al-Addabu Sa'liyah: Sesungguhnya melatih jiwa itu diajari, dibiasakan beradab, memaafkan dan berbuat baik. Jika perbuatan baik terus berulang maka akan menjadi kebiasaan dan jadi tabiat/karakter/watak dan adab-adab kebiasaan akan jadi watak-watak atau karakter-karakter yang terbentuk berikutnya.

\section{Metode Pelayanan}

Metode yang ketiga adalah metode pelayanan, adapun orientasi dari metode pelayanan ini adalah terwujudnya pengembangan diri. Yang diharapkan dari anak adalah orang tua dapat melayani, memfasilitasi, melatih, dan memberikan hal-hal yang 
dibutuhkan oleh anak, mendampingi, memotovasi serta menginspirasi diri anak. Hal yang orang tua lakukan demikian agar anak dapat mengembangkan dirinya, kemampuan semakin bertambah, kecerdasannya semakin bertambah.

Berdasarkan pada QS. At-taubah ayat 128 yang artinya: “Telah datang dari kalian seorang Rasul dari diri kalian sendiri, dia akan merasa sedih/kesulitan, dia sangat peduli terhadap kalian dan sangat pengasih dan penyayang terhadap orang - orang beriman."

Berdasarkan HR. Muslim: "Allah akan terus menyertai seorang hamba, selama hamba it uterus melayani atau menolong orang lain." Dikutip dari kisah Mujahid seorang tabi'in rahimahullah menceritakan tentang gurunya yaitu Abdullah Ibn Umar beliau berkata. Aku menemani Ibn Umar untuk melayaninya, namun yang terjadi dia yang melayani aku. Bahkan dialah yang menaikkan aku keatas kuda ku dan dia pulang merapikan baju-bajuku.

Jadi, inilah yang dimaksud dengan metode katsayan, yang sesungguhnya terambil dari ayat-ayat $\mathrm{Al}$-Qur'an dan Hadits-hadits yang shahih juga dari ungkapan para ulama dan para sahabat radiyallahu'anhumma ajma'in.

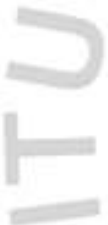

I. PElaksanaAn Kegiatan

II. KEGIATAN PARENTING INI MELIBATKAN SELURUH ORANG TUA DAN GURU YANG ADA DI RA VINNAJA KABUPATEN MUARO JAMBI. PELAKSANAAN KEGIATAN PARENTING DILAKSANAKAN DENGAN BEBERAPA TAHAPAN YAITU:

1. TAHAP Pertama AdAlah PenYAMPAian MATERi PARENTING

Kegiatan penyampaian materi dipandang akan berhasil sesuai dengan tujuan yang ingin dicapai jika materi yang disajikan tersusun dan terencana dengan baik sesuai kondisi orang tua yang ada di daerah kasang pudak Kabupaten Muaro Jambi tersebut. Oleh karenanya sebelum kegiatan dilaksanakan maka tim pengabdi menyusun materi secara terstrukur dan logis dengan harapan bahwa materi-materi yang akan disajikan pada kegiatan parenting tersebut berkesinambungan antara satu materi dengan materi yang lain.

a. Materi pelatihan yang disajikan selama kegiatan parenting sebagai berikut:

1) Tumbuh kembang anak usia dini 
2) Teori pola pengasuhan

3) Metode pengasuhan katsayan (pembiasaan, pembiasaan, dan pelayanan)

b. Tim Pengabdi

Kegiatan pengabdian masyarakat yang berupa kegiatan parenting bagi orang tua dan guru dilakuan oleh 3 orang yaitu:

1) Siti Marwah,S.Ag, M.Pd.I

Dosen Prodi Pendidikan Islam Anak Usia Dini STAI Ma’arif Jambi

2) Vivi Yumarni, M.Pd.I

Dosen Prodi Pendidikan Islam Anak Usia Dini STAI Ma'arif Jambi

3) Nurul Annisa Dewantari Nasution, S.Psi, M.Pd

Dosen Prodi Pendidikan Islam Anak Usia Dini STAI Ma'arif Jambi

\section{Tahap kedua, pelaksanaan kegiatan lomba mewarnai}

Kegaiatan ini diiukuti oleh 12 orang siswa/i atau anak-anak didik di

RA Vinnaja tersebut. Kegiatan ini menghasilkan karya mewarnai yang bagus-bagus dan mereka semua mendapatkan reward berupa jajanan.

Kegiatan ini diikuti dengan suasana yang sangat ceria terlihat dari wajah mereka yang tersenyum saat lomba tersebut.

\section{Dokumentasi}

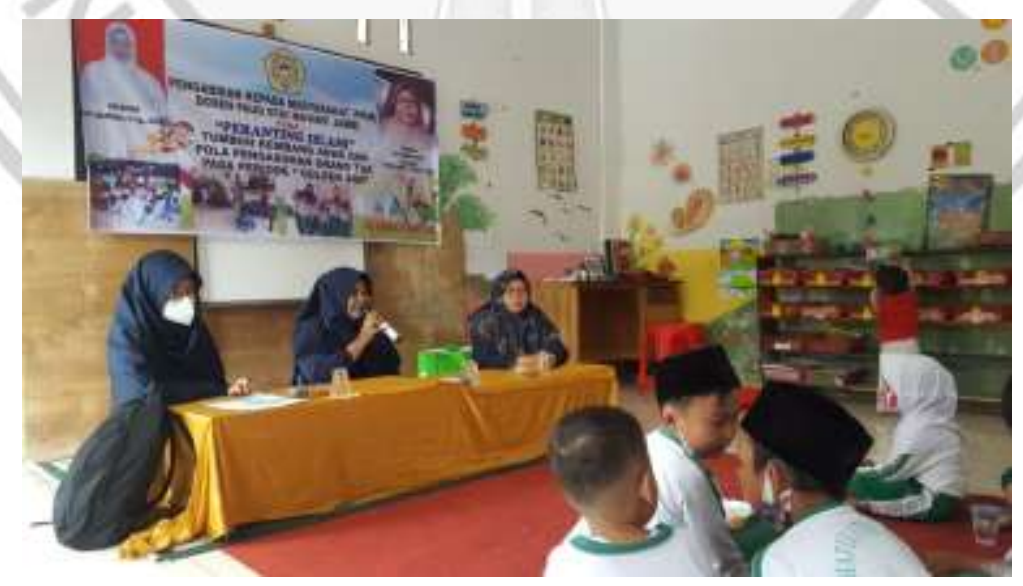

Gambar 1. Pembukaan sekaligus penyampaian materi oleh Bu Siti Marwah, S.Ag., M.Pd. 


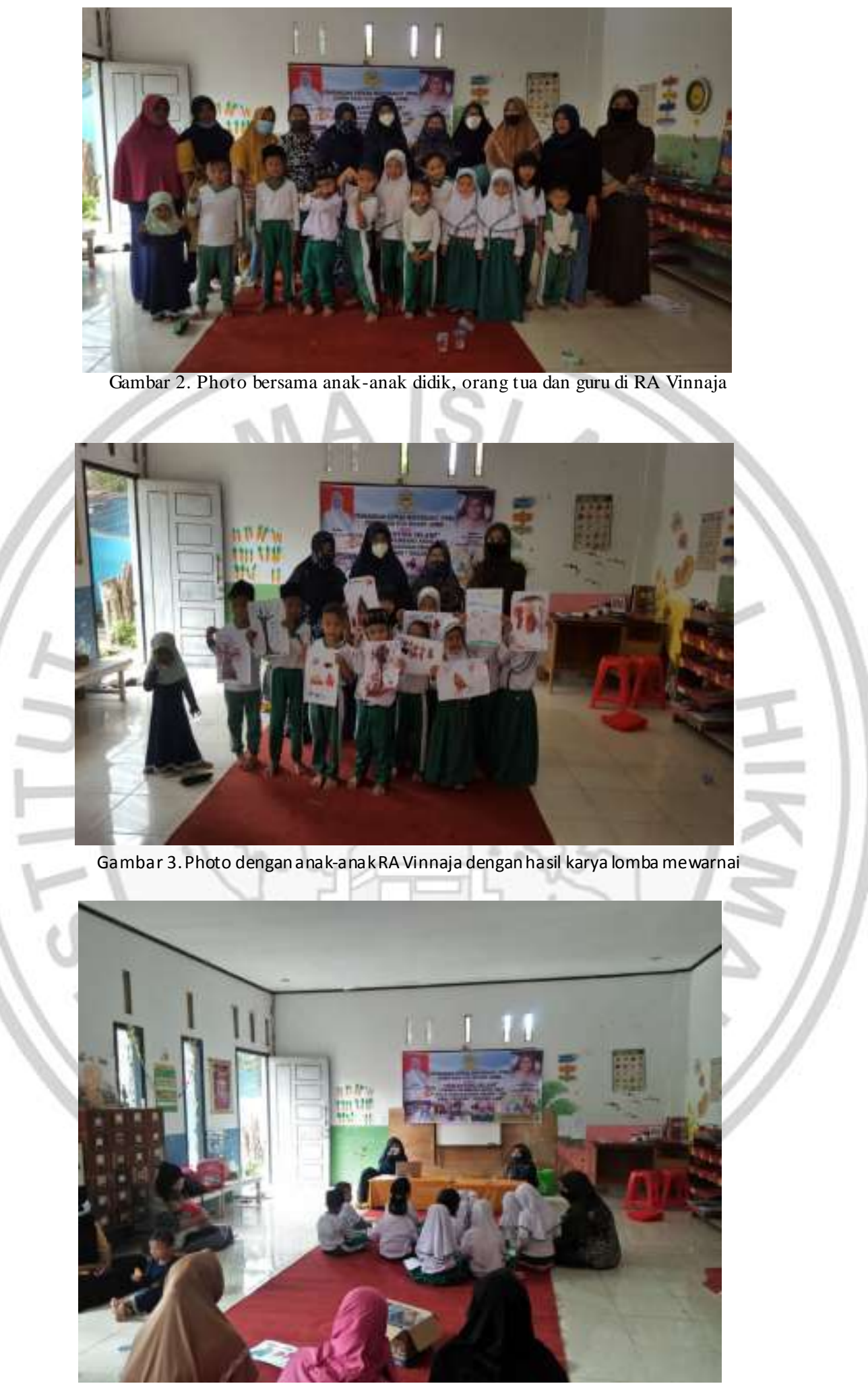

Gambar 4. Penyampaian materi oleh Bu Nurul Annisa D.N, S.Psi, M.Pd 


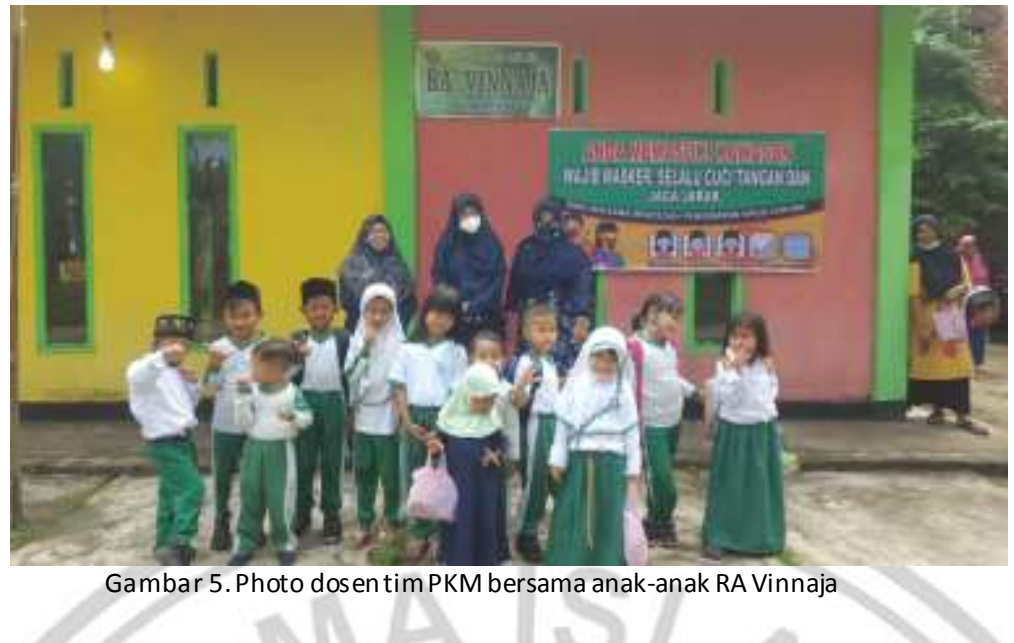

\section{PENUTUP}

\section{Simpulan}

Dalam mendidik anak seorang ayah dan ibu harus merawat dan menjaga anak ketika didalam kandunganbukan saja ketika anak sudah lahir atau pun dewasa. Anak akan mersa aman dan nyaman berada di dekatayah apabila ayah dan ibu memberikan kasih sayang yang tulus pada ananya. Orang tua turut memberikan kontribusi penting bagi perkembangan anak, pengalaman yang dialami bersama dengan ayah dan ibu, akan mempengaruhi seorang anak hingga dewasa nantinya. Peran serta perilaku pengasuhan ayah dan ibu mempengaruhi perkembangan serta kesejahteraan anak dan masa transisi menuju remaja. Perkembangan kognitif, kompetensi sosial dari anak-anal sejak dini dipengaruhi oleh kelekatan, hubungan emosional serta ketersediaan sumber daya yang diberikan oleh ayah. Ayah merupakan salah satu figur yang berperan dalam keluarga. Fungsi dan tugas ayah tentutidak sama dengan ibu. Ibu lebih berorientasi pada pengasuhan sedangkan ayah lebih kepada perlindungan dan penanaman nilai-nilai. Peran ayah dalam keluarga sangat penting dalam mendidik dan menjadi ayah yang bisa memimpin keluarga, dimana ayah bertanggung jawab atas pengajaran moral pada anak. Sosok seorang ayah adan ibu sangat mempenggaruhi pertumbuhan dan perkembangan anak usia dini dengan melalui berinteraksi dengan ayahnya sehingga anak mendapat pengalamanyang akan ia contoh. Kedekatan antara seorang ayah dan ibu, dan anak membuat sebuah keharmonisan didalam keluarga sosok ayah dan sosok seorang ibu tidak dapat digantikan oleh siapa pun, masing- masing mereka sudah memiliki peran. Ayah dan anak saling berinteraksi akan mengakibatkan perkembangan emosional yang baik pada anak karena anak dapat merasa senang dan percaya diri yang tinggi. Ketika peran ayah dan Ibu sudah dijalankan dengan baik maka perkembangan kognitif anak akan baik akan mempengaruhi kompetensi sosial pada anaknya sehingga hubungan emosional antara orang tua dan anak dapat berkembang dengan baik hal ini akan berdampak positif untuk masa selanjutnya pada anak. 


\section{Saran}

Adapun sarannya adalah kegiatan parenting ini tidak hanya sebatas penambahan ilmu semata untuk guru dan orang tua, akan tetapi akan lebih baik dipalikasikannya ilmu-ilmu yang didapat dari materi-materi tentang parenting ini kepada anak-anak usia dini sehingga dapat terwujudnya tumbuh kembang yang optimal bagi anak usia dini ini. Dan hak-hak anak terpenuhi dengan baik akan kebutuhan agama dan kebutuha lainnya dalam hal duniawi.

\section{DAFTAR PUSTAKA}

Dagun, S. M. (2002). Psikologi Keluarga (2nd ed.). Jakarta: PTRineka Cipta.

Djamarah, S. B. (2014). Pola Asuh Orang Tua dan Komunikasi dalam Keluarga. Jakarta: PT rineka cipta.

Morrison, George S. (2012). Dasar-Dasar Pendidikan Anak Usia Dini (PAUD). University ofNorth Texas: Indeks.

Papalia, Diane E. (2012). Experiences Human Development. USA: Mc Graw Hill, Jahja, Y. (2011). Psikologi Perkembangan. Jakarta:Kencana.

Qodariah, L., \& Pebriani, L. V. (2016).Recognizing Young Children's Islam Anak Usia Dini. Pendidikan Anak Usia Dini, II.

Expressive Styles of Emotions (2-6 Years Old). Proceedings ofthe 3Rd International Conference on Early ChildhoodEducation (Icece 2016), 58.

Safira, T., \& Saputra, N. E.(2009). Manajemen Emosi. Jakarta: PTBumi Aksara.

Vivi, A. (2018). Fatherhood Dalam Perkembangan dan Pendidikan 